\title{
The First Year Colloquium: Creating a Safe Space for Students to Flourish
}

\author{
Myriam Vuckovic \\ Georgetown University \\ mv225@georgetown.edu \\ Brian Floyd \\ Georgetown University \\ Joan Riley \\ Georgetown University
}

\begin{abstract}
College is one of the most formative times in an individual's life. Its intense living-learning environment can promote students' extreme self-confidence and positive development, or alternatively, can result in low levels of well-being. The first year in college is an opportunity for faculty and staff to engage with students to belp them build learning skills, a sense of responsibility, and ownership of their college experiences. The aim of this study was to examine the impacts of a first year colloquium on student well-being. In the fall of 2015, 91 entering first year students at Georgetown University in Washington, DC, participated in a mixed method study using written reflection responses and in a pre/post survey using Keyes (2009) Mental Health Continuum-Short Form (MHC-SF). Gains were seen in psychological well-being with an increase in flourishing as compared to early semester moderate flourishing. Students reported that having one course that provided a safe space for them in their first semester, and that addressed well-being in college, was critical for them to succeed and thrive in their first year.

Key words: college students, flourishing, well-being, first-year experience
\end{abstract}

\section{Introduction}

For young American adults, their college years represent the most formative and formidable transition of their lives, and a time of great excitement, personal growth and learning. It is also a time when many young people experience anxiety, stress and a decreased sense of personal wellbeing (Eagan, et al., 2015; American College Health Association, 2015). An abundance of research has shown how important the first-year experience is for the development of not just academic and intellectual skills but for the formation of the students' emotional, social, physical and spiritual wellbeing (Upcraft and Gardner, 1989; Padgett, 2011; Bowman, 2010). Consequently, the first year presents an important opportunity for faculty and staff to engage with the students and help them build life-long cognitive and learning skills, a sense of responsibility and altruism, as well as critical life skills (Pascarella \& Terenzini, 2011; Padgett 2011).

Over the past three decades, the vast majority of accredited US universities and four-year colleges have recognized this opportunity and have introduced first-year seminars as a tool to improve the transition and learning experience of new college students (Padgett \& Keup, 2013). Research has shown that seminars taking a holistic approach, addressing academic and nonacademic topics, have the largest impact on students' academic success and personal well-being (Swing, 2002; Barefoot, 2005). About 60\% of first year seminars offered in the US take this wholeperson, student-centered approach (Tobolowsky \& Associates, 2008). Multiple studies have looked 
at the impact of first-year seminars on student outcomes, including student retention and graduation rates, academic achievement, and life-long learning orientations, demonstrating the positive impact of these courses on key educational outcomes (Cuseo, 2009; Padgett, Keup \& Pascarella, 2013).

One area that has not been studied in depth is the role that first-year seminars can play in fostering student psychological well-being, a more holistic measure of student success (Ryff \& Singer, 2008; Bowman \& Kitayama, 2009). Ryff identifies self-acceptance, positive relations with others, autonomy, environmental mastery, purpose in life, and personal growth as facets of wellbeing. According to the World Health Organization (WHO), 'mental health is defined as a state of well-being in which every individual realizes his or her own potential, can cope with the normal stresses of life, can work productively and fruitfully, and is able to make a contribution to her or his community' (WHO, 2014). First year seminars may be uniquely well positioned to address these key elements and to inform programs about students' needs and to assess the impacts of first year programming through pre-post-design (Seifert, 2005).

According to the 2015 NCHA survey (ACHA, 2015), undergraduate students reported that over the preceding 12 months, anxiety, sleep difficulties, depression and stress had a negative impact on their academic performance: $23.4 \%$ of students identified anxiety as affecting their academic work, $14.8 \%$ depression, $22.0 \%$ reported negative impacts from sleep difficulties, and 32.5\% of students perceived stress as a major factor negatively influencing their studies (ACHA-National College Health Assessment, 2015).

The Gallup-Healthways Well-Being Index (Rath \& Harter, 2010; Sears et al., 2014) is an evidence-based instrument that provides a comprehensive description of what it means to be thriving. It identifies five elements that have been validated against community outcomes such as life expectancy, income, and mortality rates (Gallup-Healthways, 2009.) The five elements that describe the interplay among many aspects of life are: (1) having a sense of purpose (liking what you do each day); (2) social well-being (relationships and love in your life); (3) financial well-being; (4) community engagement; and, (5) physical well-being. The Gallup-Purdue Index measures these five well-being elements in college graduates with findings that only $11 \%$ of all U.S. college graduates are thriving in all five elements of well-being: (1) having a sense of purpose (liking what you do each day); (2) social well-being (relationships and love in your life); (3) financial well-being; (4) community engagement, and, (5) physical well-being. According to Gallup, more than one in six college graduates are not thriving in any of these elements. These measures of well-being are significant, since they influence vital outcomes such as worker productivity, absenteeism and healthcare costs (Gallup, 2015). Gallup has found that if college graduates felt emotionally supported during college, the odds that they are deeply engaged in their work doubled, and the odds that they are thriving in their overall well-being tripled. There appear to be very strong correlations between the experiences students have while in college and their success, fulfillment and overall well-being later in life. Having at least one professor who made them excited about learning, feeling that professors cared about them as a person, and having a mentor who encouraged their goals and dreams were the three most important elements in the graduates' college experience relating to their well-being and thriving later in life (Brandon Busteed, Executive Director of Education \& Workforce Development for Gallup, Georgetown University, May 24, 2016).

\section{Well-Being and Flourishing in College}

Findings about well-being show the essential role that colleges and universities, and particularly faculty and staff, can play in supporting students' well-being during their college years and their capacity to thrive later in life. It is our hypothesis that holistic, student-centered first-year seminars can serve as an ideal entry point to create a nurturing and emotionally supportive environment for

Journal of the Scholarship of Teaching and Learning, Vol. 19, No. 2, March 2019.

josotl.indiana.edu 
new students, one that allows them to build meaningful relationships with fellow students, faculty, and academic advising staff.

The concept of human flourishing describes a multi-faceted state of well-being. The act of flourishing has been described as "liv[ing] within an optimal range of human functioning, one that connotes goodness, generativity, growth, and resilience" (Fredrickson and Losada, 2005). Keyes (2007) developed the Mental Health Continuum-Short Form (MHC-SF) to measure well-being or what he describes as "flourishing" or positive mental health. Flourishing, the optimal state of mental health and well-being, is at the positive end of this mental health continuum. Languishing is found at the opposite end. Languishing can be defined as the "absence of mental health" (Keyes, 2002), but not necessarily a state of mental illness.

The MHC-SF has been included in the toolkit of the Bringing Theory to Practice (BTtoP) national imitative that encourages and supports colleges and universities to address well-being as an essential component of student engagement, civic purpose and preparation for a meaningful life. It is a 14-item self-rating assessment tool that combines the three components of well-being: emotional, social, and psychological. The MHC-SF recognizes that mental health is critical to student success. The MHC-SF aligns with the WHO definition of mental health and provides an assessment of positive mental health as more than the absence of mental illness but, rather, as the presence of high levels of emotional, psychological, and social well-being (WHO, 2014).

Low (2011) examined first-year college students using Keyes (2007) MHC-SF. She found $69.1 \%$ of students flourishing, $29 \%$ moderately mentally healthy, and $1.9 \%$ languishing. These results demonstrate greater flourishing than in Keyes' 2006 study, which found 47.9\% of high school students flourishing but only $20 \%$ of the general adult population (Keyes, 2005). Low also suggests that students entering highly-selective higher education institutions may be more likely to be flourishing.

First-year seminars can provide a safe space for young adults to practice how to reflect on and talk about their experiences, to explore their personal and academic strengths and weaknesses, to build personal relationships with faculty and staff, and to develop social and psychological wellbeing skills. In fact, self-reflection and mindfulness play crucial roles in the development of psychological well-being skills such as "having a sense of purpose in life," "accepting and thinking positively about oneself," and "seeking opportunities for personal growth" (Bowman, 2010). Reflection can also serve as an effective tool for emotional self-regulation (Herwig, 2010).

Recognizing its crucial role in students' flourishing, Georgetown University's School of Nursing \& Health Studies developed a small, interdisciplinary First Year Colloquium (FYC), which explicitly focuses on student well-being. The different sections of the course address various health topics chosen by the course faculty, including college health issues, health disparities, bioethics, scientific theory, and end-of life care. The overall goal of the course is to ease the students' transition to college, and to equip them with the tools necessary for academic and personal success. The FYC is taught across all four majors (Global Health, Health Systems Administration, Human Science, and Nursing), allowing students to get to know each other across departments and to work in interdisciplinary teams. Each of the seven sections (16-18 students each) is co-taught by one faculty member and one member of the academic advising staff.

The goal of the FYC is to introduce new students to the programs, resources, and opportunities offered on campus, including the Career Center, Counseling and Psychiatric Services (CAPS), Academic Resource Center, and Campus Ministries. Students learn about time management and academic enrichment opportunities, health careers, internships, and study abroad programs. All sections include weekly discussions about students' common concerns, such as managing the transition to college, and student health issues. Several of the sections offered anonymous emotional intelligence testing (EQI) to the students, followed by a class discussion led by an expert from

Journal of the Scholarship of Teaching and Learning, Vol. 19, No. 2, March 2019.

josotl.indiana.edu 
CAPS. Each section also organizes co-curricular activities such as a walk through the school's historic neighborhood, a major league baseball game, or a community-service project. Specific goals include those experiences identified by Ryff (Seifert 2005), including promoting interaction and meaningful connections among students, professors, and academic advising staff, positive diversity interactions and moments of "challenge" between faculty and students, as well as developing reflective practices as a way to foster students' well-being and to promote student learning.

\section{Methods}

\section{Design and Participants}

This mixed-method design study, using qualitative and quantitative assessment, examined the impacts of the FYC on dimensions of students' flourishing and well-being in the Fall semester of 2015. The university's Institutional Review Board approved this study (IRB 2015-1016).

All students enrolled in the FYC were invited to participate. The FYC is a required course for firstyear students and students do not self-select to enroll. The Fall 2015 cohort included 22\% male and $78 \%$ female students. The cohort' cultural/ethnic background was 19\% Asian, 10\% Black or African American, 10\% Hispanic, 7\% two or more races and 54\% White. In terms of their academic ability, the students accepted that fall had performed at 96.2 Percentile High School Rank, had a middle $50 \%$ SAT in CR of 640-750, and a middle 50\% SAT in Math of 650-740, with a, 20\% acceptance rank to the program. ${ }^{1}$

Students younger than 18-years-of-age and those not giving consent were excluded from the study. Of the 115 students enrolled, 91 completed pre and post surveys. The majority of the 115 students enrolled in the FYC completed four reflections and gave written consent to have their reflections included in the study $\left(1^{\text {st }}\right.$ Reflection: $N=92 ; 2^{\text {nd }}$ Reflection: $N=89 ; 3^{\text {rd }}$ Reflection: $N=63$; Final Reflection: $\mathrm{N}=70$ ). To analyze the qualitative data, the students' reflections were coded and analyzed thematically.

\section{Instruments}

Keyes Mental Health Continuum-Short Form (MHC-SF) (Keyes, 2006) was used to measure flourishing. A total flourishing score was calculated, as were individual sub-scores for emotional, social, and psychological well-being. Categorical criteria were followed to determine mental health diagnosis. MHC-SF data was collected using Qualtrics.

As part of the FYC curriculum, all students were asked to write three reflections throughout the semester (in September, October and November), as well as a final reflection at the end of the semester. All seven sections shared the same reflection topics and used similar pedagogical techniques. First, the students had the opportunity to answer the prompt anonymously in class, using an electronic polling mechanism (www.polleverywhere.com). The results appeared instantly as a word cloud for everyone to see, which triggered an in-class discussion of the question and the students' responses. After the discussion, students had the opportunity to either write their personal reflections in class or at home, and to share them on their section's e-portfolio site. The final reflection of the semester was completed individually and only shared with faculty and advising staff. The three common reflections were:

\footnotetext{
${ }^{1}$ Academic ability stats are regarding the accepted students that year
} 
1. What are you most anxious or fearful about as you begin the semester? What are you most excited about or looking forward to as you begin the semester?

2. What are the obstacles preventing you from being your best self? Are there changes you need to make? What will you do differently?

3. What is your definition of success for yourself this semester? How are you doing in meeting this definition? What has been helpful?

The end of the semester reflection prompt asked the students to reflect on at least two of the following questions:

1. Connection: Describe an experience this semester when you made a meaningful connection between different things you are learning about well-being and your own life- a connection about which you had not previously seen the significance. Why was that particularly meaningful to you?

2. Relationships: Describe the person(s) and/or moment(s) this semester that has most contributed to your learning with regard to perspectives or persons about whom you previously knew little. Why and how has that person, group, or time been so important to your learning?

3. Challenge: Describe a time this semester when you encountered a significant challenge or obstacle to your own sense of your well- being. What happened, and what did you learn from that difficulty?

4. Self-Awareness: What about your experience in this course was meaningful for you personally or has mattered to you most? Tell us about that.

\section{Findings}

Using quantitative data from the pre- and post FYC survey of 91 students (out of the 115 freshmen who took the class) as well as qualitative data from the four written reflections, this study explores the question whether the FYC provided a safe space for new students to verbalize their thoughts, concerns, and questions. The data clearly shows that for the students, their weekly colloquium class was a place where they felt safe and comfortable sharing their positive as well as negative experiences as first semester college students with each other, their professors and academic deans.

In the pre-post survey, students were asked whether they agreed or disagreed with the statement: 'This class is a safe space to verbalize questions and concerns.' Scores ranged from 1 (Strongly Disagree) to 4 (Strongly Agree). The students took the survey at the beginning of the semester and then again at the end of the semester. In the beginning of the semester $\left(3^{\text {rd }}\right.$ week of class), the mean score reported was 3.37 (SD 0.61). At the end of the semester (last week of class), the score reported was 3.59 (SD 0.52). Using a paired samples t-test, the difference of 0.22 had a pvalue $<.001$, showing that students increasingly felt that their colloquium class was a safe and comfortable environment to talk about their experiences and to ask questions about life at Georgetown.

This survey result is also very much supported by the qualitative data. The thematic analysis of the students' reflections reveals a lot about the students' experiences throughout the course of their first semester. They write about their expectations, hopes, fears, doubts, struggles, successes, failures, and overall physical and psychological well-being. They reflect on who they are as a person and who they hope to become during the four years ahead. They challenge themselves to not only be better students academically but better people in the social and emotional care of themselves and others. Their experiences as first-year students are remarkably similar: most students struggle to balance their academic work and their extracurricular activities; they long to find their niche on 
campus and to establish meaningful relationships; they try to come to terms with the reality that they are no longer at the top of their (high school) class; they learn how to navigate a new environment far away from parents and friends; and they begin to take full responsibility for their own physical and mental health. Many students identified getting enough sleep, missing home, feeling lonely, making new friends, and dealing with anxiety and stress about their academic performance as the key issues they struggled with while transitioning into college. The following reflection contains many of the key themes addressed by the students:

"I know many people say the transition to college is difficult, but I did not realize just how difficult it would be until I arrived on campus. Being away from home and my family took a toll on me-it wasn't necessarily just the unfamiliarity but adjusting to college in general. I missed my friends back home terribly. Because I am a naturally introverted person, being outgoing and making new friends is not easy for me. As a result, I felt lonely and like an outsider at the beginning of the school year.... Furthermore, the academic system was new and stressful-unlike high school. I learned that there are only a few exams and/or papers a year in college. I realized that if I made a mistake one time, it would be almost impossible to recover my grade. This made me extremely fearful, even before my academic classes began. While a little stress can be good to motivate someone to work hard, I realize now that the stress I felt was so great that it actually made me more unproductive. That level of stress took a toll not only on my mental and emotional health, but also on my physical health, for I began to eat less, exercise less, and lose sleep." (Final student reflection \#64, FYC, December 2015)

The FYC was specifically designed to help ease this transition, to reduce anxiety and stress, and to provide students with the tools to flourish in college - both academically and in their personal lives. In their reflections, many students write about the positive impact the FYC had on their adjustment to college. Overwhelmingly, they see the class as a safe space to verbalize their concerns, to ask questions, and to discuss their positive as well as negative experiences during their first semester in college. The positive assessment of the FYC reported in the quantitative survey results is compellingly echoed in the students' reflections. The following quote reflects the views expressed by many of the students:

"This course has made me lose the feeling of intimidation from my classmates. I have struggled and so many of my classmates are on the same boat. The anonymous polls at the beginning of class made me realize that although everyone here works hard, college was not an easy transition for everyone in some aspect.... I really hope that other students can benefit off of this open and safe environment, where the instructors truly care about their students... Overall I just developed a sense of comfort from this course." (Final student reflection \#1, FYC, December 2015)

The main themes raised in this reflection are recurring in many others, including the realization that all students are experiencing similar challenges and anxieties, and the recognition that their university, and particularly the FYC, is a truly caring and supportive environment. As another student reflects:

"I think the most outstanding fact of this course for me was learning how many people there are that are offering themselves and their services to me as a resource while I'm studying and living here on the [campus]... This course has shown me that on our campus especially, there is a sense of a caring community looking out for your best interests." (Final student reflection \#4, FYC, December 2015)

Journal of the Scholarship of Teaching and Learning, Vol. 19, No. 2, March 2019. josotl.indiana.edu 
Many students commented positively on the pedagogical tools used to engage the class in discussions about their feelings and experiences, particularly the use of anonymous electronic polls (www.polleverywhere.com) to kick off class discussions on student well-being:

"I really liked the anonymous online polls we did during some classes. It allowed my peers and me to be honest and open because it was anonymous, so I felt like I was really getting privilege to see people's true responses to pretty hard-hitting questions about stress, anxiety, and adjusting to college life in general. That was really eye opening for me because I did not feel alone in my homesickness and other feelings of doubt (I'm not smart enough to be here, only I am having difficulty settling in and finding people I like, etc.) and I found that a lot of other people in my colloquium were facing similar challenges. So I think the online polls were a great vehicle for discussion and learning as far as my first semester of college and freshman experiences go." (Final student reflection \#8, FYC, December 2015)

"Hearing that it was okay to be overwhelmed, stressed, and even unhappy at times was very meaningful to me since I have always been under the impression that exhibiting any of these feelings was akin to showing weakness. It was as if something was wrong with you if you felt stressed out or unhappy because everyone else had it all figured out. Seeing the poll everywhere questions and understanding that many other people were facing similar challenges and having struggles of their own helped me realize that no one's life is truly perfect and that it never has to be." (Final student reflection \#29, FYC, December 2015)

Similarly, the students appreciated the important role that reflection played in the course and how it allowed them to become more self-aware and mindful about their experiences. Learning how to reflect and doing it regularly in class helped them to cope with many of the stressors they experienced and provided them with a useful tool for the remainder of their college career and beyond:

"My favorite aspect was the reflections. I never encountered a course before that asked so much deep thinking and soul searching. I learned more about myself, my goals, and my approach to life in this course than I ever have before. I am not usually one to self-reflect, and I certainly didn't think I would have the time to do so outside of classes, let alone during our weekly sessions. These discussions helped me open up to my friends and start those conversations outside of class too. It made my experience much better overall." (Final student reflection \#11, FYC, December 2015)

"In the beginning of our colloquium class, we have a time to reflect on the past week, and each of us are encouraged to talk about whatever highs or lows we have experienced within the past week. During this part of class, I have learned a lot about myself and others, whom I previously knew little about. Some people were very open to sharing whatever their stressors were or how they were doing for the week. Through this activity, I learned not only about their lives, but I also learned about myself. I learned that I too was very open and comfortable sharing whatever got me high or low throughout the week. I also learned that I found the support of a group helpful. Many people could relate to my lows, and it made me happy to share my highs." (Final student reflection \#17, FYC, December 2015)

"I think the focus on reflection was the most meaningful aspect of the class to me.... I feel like I've changed a lot as a person because of this course without realizing it. I'm much more in tune to how I am feeling and I can strategize ways to confront and deal with those

Journal of the Scholarship of Teaching and Learning, Vol. 19, No. 2, March 2019. 
emotions.... Reflecting on our experience transitioning to college and then discussing it with the class was extremely valuable to me too.... People shared many different ideas on what to do in certain situations and we all felt very comfortable to talk. I've seen this translate into my everyday life. The biggest change I've noticed about myself since coming to college is that I'm so much more open to expressing my feelings and thoughts to people." (Final student reflection \#21, FYC, December 2015)

"Before college, I never saw the significance of mental health. Back in high school, I worked all the time and never designated some time for myself to rewind and reflect. This semester in this class, I learned the concept of reflection and why it is important. Because of reflection, I am able to get a deeper understanding of "who I am" in the sense of my contribution to the rest of the world. Also, reflection aids my mental health by allowing me to realize the positive change that occurs in my life. (Final student reflection \#62, FYC, December 2015)

Feeling comfortable and safe in a class with fellow students, professors, and academic advising staff helped the students to form meaningful relationships and to overcome many of the challenges they encountered during their first semester in college. As we know from the recent Gallup study, the correlations between experiences students have in college and their success, fulfillment, and overall well-being later in life are strong. In the Gallup study, forming positive mentoring relationships with professors and other adults on campus was the most important element in the graduates' college experience relating to their well-being and thriving later in life (Busteed, 2016). The FYC is designed so that students very early on in their college career get the opportunity to connect on a personal level with a faculty member and an academic advisor. The weekly discussions and co-curricular activities are opportunities for students, faculty and academic advising staff to get to know each other and to share their personal experiences in a low-stress, grade-free environment.

The qualitative data shows that the First Year Colloquium clearly supported the students in their search for overall physical, emotional, social, and psychological well-being during this time of transition:

"This class was extremely applicable to my life this semester as the course material was directed toward the wellbeing of college freshmen. It gave me a safe outlet where I felt comfortable to share my true feelings and allowed be to shamelessly receive advice from my peers and professors. We learned about sleep, study habits, relationships, and more. These were all very helpful topics during my transition into college." (Final student reflection \#27, FYC, December 2015)

"I think the most meaningful aspect of this course for me was having an emotional outlet to others that are sharing my experience. As a lot of kids in my class are all pre-med and experiencing the stress and workload that I am, it is very comforting to hear how they go through life and cope with the same things I deal with... Because of this class, I have sparked some new friendships that I really do hope last. Also, I feel very comfortable knowing that my instructors are there for me if I ever need anything. This alone means a lot to me." (Final student reflection \#31, FYC, December 2015)

"The most meaningful part of this course for me was just the open discussion.... It helped me form bonds and meet other NHS students but more importantly it really helped in my transition... Also, our instructors were so kind and made us feel like a family. All of my

Journal of the Scholarship of Teaching and Learning, Vol. 19, No. 2, March 2019.

josotl.indiana.edu 
friends in other schools were jealous when I tell them that we have a class like this. It was a really worthwhile experience for me, personally." (Final student reflection \#30, FYC, December 2015)

"My instructors put my fears about college and the future aside because they have made it a point in class to show that no one has it all together all of the time, even though it may look like it. We are all people going through our own journeys. They have provided a network of support and an environment in which I am safe to express myself, and it is one of the first times that I have ever felt like this in my life." (Final student reflection \#35, FYC, December 2015)

"The part of this course which was most meaningful for me personally was the fact that I felt like I left the class with a personal relationship with my professors and peers in the class... Hearing the shared experiences that the other students in my class have had during their first semester humanized my class of 2019 and made me realize that there were other students who were all struggling with the same difficulties. Also, my professors were humanized in the same way because the class was small enough where they could all get to know each of us, at least by name. This made me feel more like an individual, and I felt validated as the person I am.” (Final Student reflection \#58, FYC, December 2015)

The students' overall positive assessment of the FYC demonstrates that the class's conscious emphasis on student well-being was a success. The different components and pedagogical tools used in the course - reflections, polls, discussions, group projects, visits from health professionals and academic resource persons, as well as joint co-curricular activities - all contributed to achieving the overall course goal: to ease the students' transition into college and to equip them with the tools necessary for academic and personal success.

The positive impact the class had on the students' overall adjustment and well-being is also reflected in the quantitative data. During the pre-post survey, students were asked to rate their mental well-being using the Mental Health Continuum Short Form (MHC-SF). The results show that the students' psychological well-being improved throughout the course of the semester and that overall, there was an increase in the number of students who were 'flourishing,' and a decrease in the number of students whose mental health was only 'moderate' (Table 1).

Table 1. MHC-SF Scores for All Students with both Pre and Post scores (N=91) (Revised)

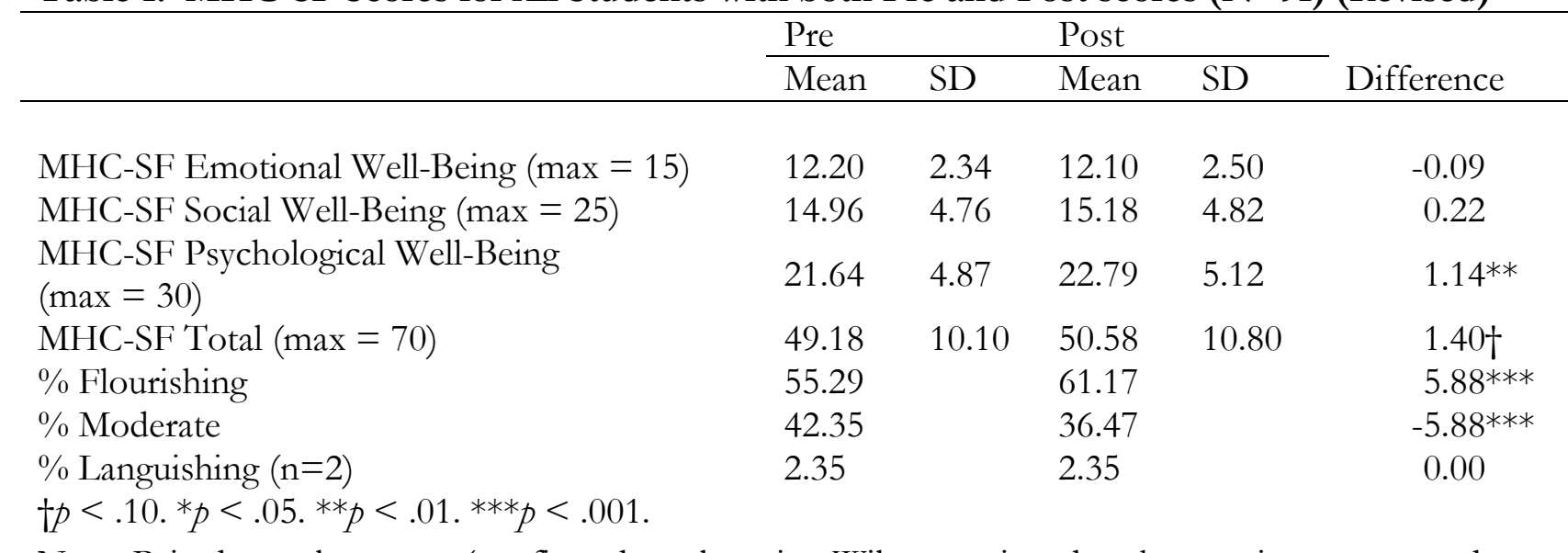

Note: Paired samples t-tests (confirmed results using Wilcoxon signed rank tests since not a random

Journal of the Scholarship of Teaching and Learning, Vol. 19, No. 2, March 2019.

josotl.indiana.edu 
sample - got same significance levels) for all statistical testing except for flourishing categories for which chi-square was used

The qualitative data supports the survey findings, with many students explicitly linking the FYC to their psychological well-being:

"Particularly in an environment like [our university], where there is a big culture around pretending to always be put-together, the things which we discussed helped us to learn that it is okay to be challenged by your mental well-being, and that there are resources on the campus that you can reach out to. This course helped me to overcome that challenge of placing my mental well-being as a priority." (Final student reflection \#58, FYC, December 2015)

"This semester in our first-year colloquium class we talked a lot about the idea of balance. To be a successful college student you can't just focus on academics, you should also engage in extracurriculars, meet new people, take time for yourself, etc. And this idea of balance also ties into your well-being. In order to be healthy you need to consider not just your physical health, but also your social and mental health." (Final student reflection \#70, FYC, December 2015)

"Overall, I believe this course was very beneficial to my growth here [on campus]. This course provided me with life-long skills that I know will benefit my effectiveness as well as my mental health." (Final student reflection \#62, FYC, December 2015)

\section{Discussion}

The percentage of students flourishing from pre- (early in the semester) to post- (end of semester) survey increased from $55 \%$ to $61 \%$. Although not statistically significant, this finding does demonstrate a trend that students increased their wellbeing. The area of psychological well-being did show significant gain from the pre- to post-survey. These gains were reported in spite of the fact that the closing of the semester comes with increased workload and stress. The end of the first semester of college is generally thought of as a time of well-being challenges due to these academic pressures and the social challenges of first year college life. At a time when well-being would seem likely to decrease, having a place for students to belong and feel safe may be responsible for the reported increases in well-being among FYC students.

The flourishing prevalence among the FYC students was higher than that found in an adult (ages 25-74) population (Keyes, 2002) but is consistent with that found in a group of American adolescents (Keyes, 2006). It is lower, however, than the prevalence found by Low (2011) in students entering their first year of college. Low (2011) postulated that students just entering college might have higher levels of flourishing due to the unique position of this transitional time in life that is often consistent with feelings of excitement and high expectations. It should be noted though that Low studied the students during orientation week and not during the course of the semester as we did, which might account for the higher percentage of students flourishing, as orientation is typically an exciting time before the actual academic work has begun. Keyes' (2002) population, in contrast, was typically older, had less than sixteen years of education, and was/had been married (Keyes, 2002). These distinctly different demographic variables may account for such a prevalence difference. Further research will be needed to unfold the difference found in our levels of flourishing and those in the work of Low (2011). Improvement in flourishing over the course of the

Journal of the Scholarship of Teaching and Learning, Vol. 19, No. 2, March 2019.

josotl.indiana.edu 
first semester of college, and in particular the psychological subscale of flourishing has not been found in any previous reported research. This may be noteworthy as addressing well-being in first year college students during the time of transition may lead to a more engaged college student and a thriving adult later in life. Further research of these students over time should be conducted.

Current literature holds that social well-being is an essential component of mental wellness and that what is most important in social functioning is how social interactions and feelings impact the mindset of the individual (Keyes \& Shapiro, 2004). However, it has been suggested that social wellness measures may be weaker predictors of overall wellbeing due to their partially "external" nature (Adams, Bezner \& Steinhardt, 1997). Indeed, although social wellness encompasses a private or "internal" component of an individual's mental state, it also uniquely holds a public or "external" component that is distinct from other realms of wellness (Adams, Bezner \& Steinhardt, 1997). Other studies have emphasized the importance of relationships and interpersonal interaction and acceptance in mental health outcomes, especially citing the importance of "belonging" (Chow, 2010; Karademas, 2005; Baumeister \& Leary, 1995). Thus, further research should examine how college students in particular are affected by social versus emotional or psychological states of being. Furthermore, if sub-diagnoses can be generated for the subcategories of the MHC-S, this tool could be used to further determine whether there are certain components of flourishing or wellness that are more or less related to academic factors in the lives of college students.

Our findings that students found a safe space in the FYC confirms the research that safe spaces enhance academic skill development by increasing self-awareness, expanding perspectives, and facilitating communication skills (Holley \& Steiner, 2005). Clearly, creating a space where first year students feel they belong is powerful for their academic and personal growth. A supportive college environment along with a sense of belonging has been identified as predictors of mental health in college (Fink, 2014) and beyond (Busteed, 2016).

\section{Limitations}

Limitations include our sample size and that all participants were from a single institution. Also, due to the fact that all freshmen in this cohort participated in the FYC it was not possible to compare our results with results from a control group. Further measures of student well-being should be employed in future research, since solely using the MHC-SF to measure well-being is likely limiting. Measures of belonging, self-knowledge, and other impacts of the first-year experience should be considered to assess well-being.

\section{Conclusion}

Our study results show that the FYC's emphasis on student health and well-being resulted in an overall positive experience for our first-year students, who felt safe and supported throughout their first semester in college. To them, the FYC was a place to unwind, to trust, to connect, and to reflect. It helped many of them to improve their social and mental well-being. The demonstrated increase in psychological well-being and flourishing validates that the FYC's explicit focus on these aspects of the first year experience can help foster overall student success, and contribute to their well-being later in life. As noted in the introduction, only $11 \%$ of all U.S. college graduates are thriving in all five elements of well-being and more than one in six college graduates are not thriving in any of these elements (Gallup 2016). Gallup's research shows a very strong association between the experiences students have while in college, and their success, fulfillment, and overall well-being later in life. If college graduates felt emotionally supported during college, the odds that they were thriving in their overall well-being tripled (Gallup 2016). By providing our students with a wellness

Journal of the Scholarship of Teaching and Learning, Vol. 19, No. 2, March 2019.

josotl.indiana.edu 
centered First-Year Colloquium experience, we are offering them the emotional support needed to help them achieve academic success as well as overall well-being throughout their college years and beyond. Based on our research results, we believe that our wellness-centered course design offers a model that can provide the emotional support so crucial for students to succeed and thrive in college and later in life.

\section{Acknowledgements}

This research was supported by a grant from the Initiative on Technology Enhanced Learning (ITEL) from the Center for New Designs in Learning and Scholarship at Georgetown University, Washington, D.C. 20057

\section{References}

American College Health Association. (2015). Undergraduate Reference Report Group, Spring 2014. ACHA National College Health Assessment II, 2015. Retrieved July 28, 2016, from http://www.acha-ncha.org/reports ACHA-NCHAIIc.html

Barefoot, B.O. (2005) Current institutional practices in the first college year. In Upcraft, M., Gardner, J., \& Barefoot, D. (Eds.). Challenge and support: Creating climates for first-year student success. San Francisco: Jossey-Bass, 47-63.

Bringing Theory to Practice. Assessment Tool. Retrieved December 16, 2017 from: https://www.bttop.org/sites/default/files/public/MHC$\underline{\mathrm{SF} \% 20 \mathrm{Brief} \% 20 \text { Introduction } \% 209.22 .2014 \text {.pdf }}$

Brown, K.W. \& Ryan, R.M. (2003). The benefits of being present: mindfulness and its role in psychological well-being. Journal of personality and social psychology, 84(4), 822. DOI: http://dx.doi.org/10.1037/0022-3514.84.4.822. Retrieved Feb 23, 2017 from http://selfdeterminationtheory.org/SDT/documents/2003 BrownRyan.pdf

Bowman, N.A. (2010). The development of psychological well-being among first-year college students. Journal of College Student Development, 51(2), 180-200. DOI: https://doi.org/10.1353/csd.0.0118. Retrieved Feb 24, 2017 from https://muse.jhu.edu/article/376346/pdf

Bowman, N. A., \& Kitayama, S. (2009). The role of psychological and subjective well-being in promoting human flourishing. Unpublished manuscript.

Busteed, B. (2016) Well-being in Higher Education. Presentation at TLISI, Georgetown University, May 24, 2016, Washington, D.C.

Chow, H.P.H. (2010). Predicting academic success and psychological wellness in a sample of Canadian undergraduate students. Electronic Journal of Research in Educational Psychology, 8(2), 473-496. Retrieved February 25, 2017 from http://www.investigacionpsicopedagogica.org/revista/articulos/21/english/Art 21 413.pdf 
Cuseo, J.B. (2009). The empirical case for the first-year seminar: Course impact on student retention and academic achievement. E-Source for College Student Transitions, 6(6), 5-7.

Eagan, K., Stolzenberg, E.B., Bates, A. K., Aragon, M., Suchard, M.R., \& Rios-Aguilar, C. (2015). The American freshman: National norms fall 2015. Los Angeles: Higher Education Research Institute, UCLA. Retrieved July 28, 2016, from https://assets.documentcloud.org/documents/2710405/The-American-FreshmanNational-Norms-Fall-2015.pdf

Fink, J. E. (2014). Flourishing: Exploring predictors of mental health within the college environment. Journal of American College Health, 62(6), 380-388. DOI: http://dx.doi.org/10.1080/07448481.2014.917647

Fredrickson, B. L., \& Losada, M. F. (2005). Positive affect and the complex dynamics of human flourishing. American psychologist, 60(7), 678. DOI: 10.1037/0003-066X.60.7.678 Retrieved February 25, 2017 from https://www.ncbi.nlm.nih.gov/pmc/articles/PMC3126111/pdf/nihms305179.pdf

Gallup-Purdue Index 2015 Report on College Graduates. Gallup, 2015. http://www.gallup.com/reports/197144/gallup-purdue-index-report-2015.aspx

Gallup. (2014) Gallup student poll: US Overall Report, Fall 2014. Retrieved July 28, 2016 from Gallup, 2014 http://www.gallup.com/services/180029/gallup-student-poll-2014-overallreport.aspx

Gallup Healthways (2009) Gallup-Healthways Well-Being Index: Methodology reports for Indexes. Retrieved December 17, 2017 from: http://www.wellbeingindex.com/hubfs/WBI Methodology.pdf?t=1483567603927

Herwig, U., Kaffenberger, T., Jäncke, L., \& Brühl, A. B. (2010). Self-related awareness and emotion regulation. Neuroimage, 50(2), 734-741. Retrieved February 25. 2017 from http://www.sciencedirect.com/science/article/pii/S1053811909013780

Holley, L. C., \& Steiner, S. (2005). Safe space: Student perspectives on classroom environment. Journal of Social Work Education, 41(1), 49-64. Retrieved February 27, 2017 from http://www.jstor.org/stable/pdf/23044032.pdf

Keyes, C. L. (2009). Brief description of the mental health continuum short form (MHC-SF). Retrieved February 27, 2017 from https://www.aacu.org/sites/default/files/MHC$\underline{\text { SFEnglish.pdf }}$

Keyes, C.L.M. (2006). The mental health continuum-short form (MHC-SF). Retrieved on July 30, 2016 from http://www.sociology.emory.edu/ckeyes/.

Keyes, C.L.M. (2006). Mental health in adolescence: Is America's youth flourishing? American Journal of Orthopsychiatry, 76(3), 395-402. DOI: 10.1037/0002-9432.76.3.395 Retrieved February 27, 2017 from 
https://www.researchgate.net/profile/Corey Keyes/publication/6812135 Mental health i n adolescence Is America \%27s youth flourishing/links/0deec52b1a7bd356bd000000/Me ntal-health-in-adolescence-Is-Americas-youth-flourishing.pdf

Keyes C. (2007). Promoting and protecting mental health as flourishing, American psychology 62 ), 95-108. Retrieved February 27, 2017 from https://www.researchgate.net/profile/Corey Keyes/publication/6482455 Promoting and Protecting Mental Health as Flourishing A Complementary Strategy for Improving National Mental Health/links/0046352b1a6f9aea9e000000.pdf

Kuh, G. D. (2008). Excerpt from High-Impact Educational Practices: What They Are, Who Has Access to Them, and Why They Matter. Association of American Colleges and Universities. Retrieved February 27, 2017 from https://pdfs.semanticscholar.org/ee0f/03b97f17219ae922831ea0322d84b59fa77a.pdf

Leskes, A., \& Miller, R.E. (2006). Purposeful pathways: Helping students achieve key learning outcomes. Washington, DC: Association of American Colleges \& Universities. Retrieved February 27. 2017 from https://www.aacu.org/publications-research/publications/purposeful-pathwayshelping-students-achieve-key-learning

Padgett, R. D. (2011). The effects of the first year of college on undergraduates' development of altruistic and socially responsible behavior. University of Iowa Research Online. Retrieved on July 28, 2016 from http:/ ir.uiowa.edu/cgi/viewcontent.cgi?article $=2437 \&$ context=etd.

Padgett, R. D., \& Keup, J. R. (2011). 2009 National Survey of First-Year Seminars: Ongoing Efforts to Support Students in Transition. Research Reports on College Transitions No. 2. National Resource Center for The First-Year Experience and Students in Transition. University of South Carolina, 1728 College Street, Columbia, SC 29208.

Padgett, R. D., Keup, J. R., \& Pascarella, E. T. (2013). The impact of first-year seminars on college students' life-long learning orientations. Journal of Student Affairs Research and Practice, 50 (2), 133-151. Retrieved February 27, 2017 from http://www.tandfonline.com/doi/pdf/10.1515/jsarp-2013-0011

Pascarella, E.T. \& Terenzini, P.T. (2005) How college affects students, Volume 2: A third decade of research. San Francisco: Jossey-Bass. Retrieved February 27, 2017 from https://edocs.uis.edu/Departments/LIS/Course Pages/LIS301/papers/How college effe cts students 534-545.pdf

Rath T. \& Harter J.K. (2010). Wellbeing: the five essential elements. New York, NY: Gallup Press.

Ryff, C. D. (1989). Happiness is everything, or is it? Explorations on the meaning of psychological well-being. Journal of Personality and Social Psychology, 57, 1069-1081 Retrieved February 27, 2017 from http://coursedelivery.org/write/wp-content/uploads/2015/02/2-Happiness-iseverything-or-is-it.pdf 
Ryff, C. D., \& Singer, B. H. (2008). Know thyself and become what you are: A eudaimonic approach to psychological well-being. In The Exploration of Happiness 2008 (pp. 97-116). Springer Netherlands.

Sears, L. E., Agrawal, S., Sidney, J. A., Castle, P. H., Rula, E. Y., Coberley, C. R., ... \& Harter, J. K. (2014). The well-being 5: development and validation of a diagnostic instrument to improve population well-being. Population bealth management, 17(6), 357-365.

Seifert, T. (2005). The Ryff Scales of Psychological Well-Being. Center of Inquiry, Retrieved December 17, 2017 from http://www.liberalarts.wabash.edu/ryff-scales/

Swing, R.L. (2002). The impact of engaging pedagogy on first-year seminars. Policy Center on the First year of College Report. Retrieved July 28, 2016 from http://www.sc.edu/fye/resources/assessment/essays/swing-8.28.02 pdfs/introduction.pdf

Tinto, V. (2001). Rethinking the first year of college. Higher Education Monograph Series, Syracuse University. Retrieved April 18, 2017 from http://nhcuc.org/pdfs/Taking_Student Retention Seriously.pdf

Tobolowsky, B. F. (2008). 2006 National Survey of First-Year Seminars: Continuing Innovations in the Collegiate Curriculum. The First-Year Experience Monograph Series No. 51. National Resource Center for The First-Year Experience and Students in Transition. University of South Carolina, 1728 College Street, Columbia, SC 29208. Retrieved on July 30, 2016 from http:// files.eric.ed.gov/fulltext/ED503181.pdf

Upcraft, M. L., \& Gardner, J. N. (1989). A comprehensive approach to enhancing freshman success. In M. L. Upcraft, J. N. Gardner, \& Associates (Eds.), The freshman year experience (pp. 1-12). San Francisco: Jossey-Bass.

WHO (2014), Retrieved on December 20, 2017 from http://www.who.int/features/factfiles/mental health/en/ 